\title{
COMMITTEE OF ASTIN:
}

Chairman: Jan Jung, Saltsjöbaden; Vice-Chairman: Hans BühlmanN, Zürich; Treasurer: Paul Thyrion, Brussels;

Secretary: Peter J. H. GREen, London.

Members: Charles C. HewitT, Northbrook; Paul Johansen, Copenhagen; Guiseppe OtTaviani, Rome; Jean Sousserrer, Paris; Henry G. Verbeek, Amstelveen.

Honorary Chairman: Édouard FRANCKX, Brussels.

The Committee is not responsible for statements made or opinions expressed in the articles, criticisms and discussions published in this Bulletin.

Le Comité rappelle que seul l'auteur de chaque publication est responsable des faits qu'il expose et des opinions qu'il exprime.

Past Chairmen: 1957-1960 Paul Johansen, Copenhagen; 19601962 Marcel Henry, Paris; 1962-1964 Robert Eric BeARD, London; 1964-1966 Hans AMmETER, Zürich; 1966-1968 Norton E. Masterson, Stevens Point; 1968-1970 Paul Thyrion, Brussels.

ASTIN (Actuarial Studies in Non-life Insurance) is a section of the International Actuarial Association (IAA). MEMBERSHIP of ASTIN is open automatically to all IAA members and under certain conditions to non-members also. Applications for membership can be made through the National Correspondent or, in the case of countries not represented by a National Correspondent, through the Secretary of ASTIN:

P. J. H. GREEN, I30, Fenchurch Street, LONDON, E.C. 3.

Members of ASTIN receive the Bulletin free of charge.

NON-MEMBERS can order a subscription to the Bulletin through:

\section{E. J. BRILL - PUBLISHER - LEIDEN (Holland).}

Cost of each number: Dutch Guilders 25.-phus postage and packing. Please send no money with your order. We will invoice you and shall then be pleased to receive your remittance.

Back numbers prior to VOLUME V, No. 2 are not available.

There are no set publication dates for the Bulletin. The frequency with which it appears varies, depending on the number and length of the contributions submitted for publication. One volume consists of three or four numbers, together about $300-400$ pages. 